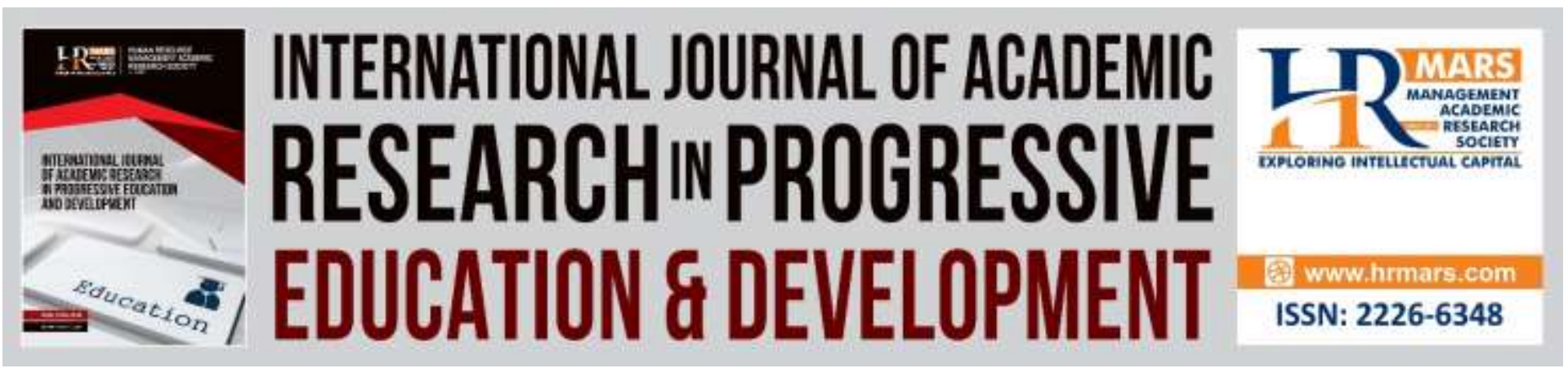

\title{
Contributory Pension Scheme and Academic Staff Commitment in Private Tertiary Institutions in South-East, Nigeria
}

Faith Chinenye Ekwunife, Femi Bamidele Egunlusi, Chikwe, Goddey Chukwudi

To Link this Article: http://dx.doi.org/10.6007/IJARPED/v8-i2/5988

DOI: $10.6007 / I J A R P E D / v 8-i 2 / 5988$

Received: 12 March 2019, Revised: 19 April 2019, Accepted: 17 May 2019

Published Online: 29 June 2019

In-Text Citation: (Ekwunife, Egunlusi, \& Chikwe, 2019)

To Cite this Article: Ekwunife, F. C., Egunlusi, F. B., \& Chikwe, G. C. (2019). Contributory Pension Scheme And Academic Staff Commitment In Private Tertiary Institutions In South-East, Nigeria. International Journal Of Academic Research in Progressive Education and Development, 8(2), 349-360.

Copyright: (C) 2019 The Author(s)

Published by Human Resource Management Academic Research Society (www.hrmars.com)

This article is published under the Creative Commons Attribution (CC BY 4.0) license. Anyone may reproduce, distribute, translate and create derivative works of this article (for both commercial and non-commercial purposes), subject to full attribution to the original publication and authors. The full terms of this license may be seen

at: http://creativecommons.org/licences/by/4.0/legalcode

Vol. 8(2) 2019, Pg. 349 - 360

http://hrmars.com/index.php/pages/detail/IJARPED

JOURNAL HOMEPAGE

Full Terms \& Conditions of access and use can be found at http://hrmars.com/index.php/pages/detail/publication-ethics 


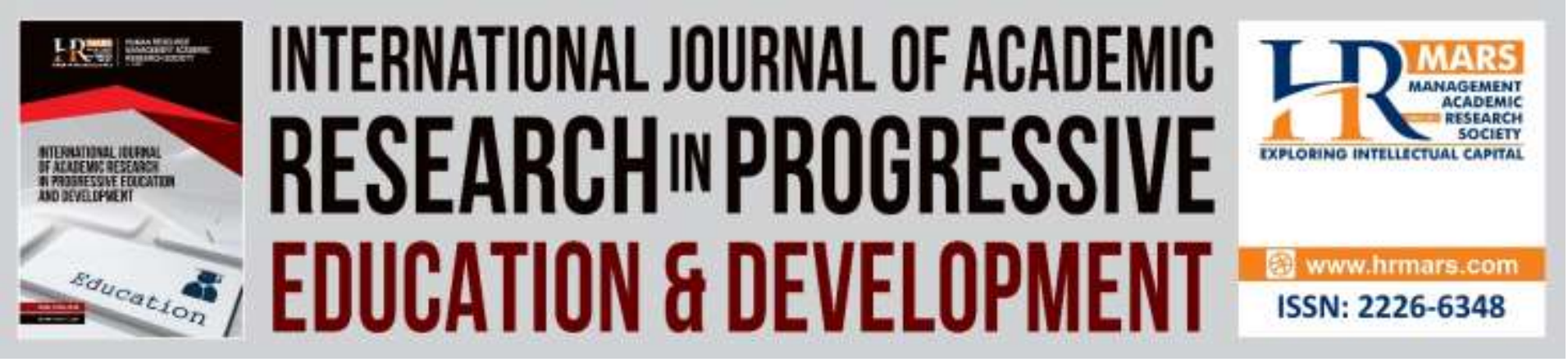

\title{
Contributory Pension Scheme and Academic Staff Commitment in Private Tertiary Institutions in South- East, Nigeria
}

\author{
Faith Chinenye Ekwunife, Femi Bamidele Egunlusi \\ Department of Banking and Finance, Evangel University, Akaeze
}

\section{Chikwe, Goddey Chukwudi}

Department of Business Management, Evangel University, Akaeze

Email: chinwuduchinyere@yahoo.com,chikwegc@evangeluniversity.edu.ng

femie_gunlusi@yahoo.com

\begin{abstract}
This study investigated Contributory Pension Scheme and Academic Staff Commitment in Private Tertiary Institutions in South-East, Nigeria. In carrying out this study, the researchers used descriptive survey design and the study covered the five eastern states (Abia, Anambra, Ebonyi, Enugu and Imo State) by focusing on selected tertiary institutions where contributory Pension scheme are practiced. The study involved a population of 611 academic staff from where Taro Yamene was used to select a sample of 242 academic staff. Data collected were analyzed using inferential statistics. The study gathered data mainly through a primary source using a five point likert scale as its major instrument. The Kruskawalis test $(H)$ was employed to test the significance of the research hypotheses while the Bowley's proportional allocation formula was used to determine each state's contribution to the sample size. The data were analyzed using Statistical Package for Social Science (SPSS) 23.0. The study concluded that there are other intricate work conditions that are needful towards ensuring substantial and sustainable commitment of the employees hence, a right mix of these work conditions should be instituted by private tertiary institutions in South-East, Nigeria. In line with the findings and conclusion, the researchers recommends as follows; Private tertiary institutions in South-East Nigeria should not only continue with the contributory pension scheme but should ensure its early remittance. Institutions yet to undertake such scheme should endeavor to do so, Paying competitive salaries especially using salary scale of federal government owned tertiary institutions can complement the contributory pension scheme and enhance employees commitment and that Beyond contributory pension scheme and other financial tools, ensuring that the social needs of unionism of the academic staff are met can help private tertiary institutions in South-East secure the commitment of their academic staff.
\end{abstract}


INTERNATIONAL JOURNAL OF ACADEMIC RESEARCH IN PROGRESSIVE EDUCATION AND DEVELOPMENT

Vol. 8, No. 2, 2019, E-ISSN: 2226-6348 @ 2019 HRMARS

Keywords: Affective Commitment, Continuance Commitment, Contributory Pension Scheme

\section{Introduction}

In a nation where government social services is at its ebb, where there is no government program for the aged, where cost of living is on constant increase and expected life span on the decrease, the fear of uncertainty is often the pain of workers who are about to exit their employment. The joy of every worker is to meet their immediate needs and have savings to overcome the rainy days ahead. In order to ensure that workers do not leave the office after contributing their youthful days in the service of organizations, pension scheme was introduced. In Nigeria, before the 2004 pension scheme reform, only workers that retired from government owned establishment enjoyed pension. This and relative job security led to the crave for government employment even by those gainfully employed in the private sector. The above scenario may be partly accountable to the monetization of the employment process in government establishment in Nigeria especially those that are regarded as grade A ministries and parastatals. Despite this penchant for government sector employment, the management of the defined benefits pension scheme (DBPS) left much to be desired. Government from federal to states established pension boards to coordinate the management of pension scheme processes with little quality in pension scheme service delivery. Little wonder why many states in the federation are owing pensioners as much as 24 months, retirees of states who are paying undergoes an excruciating process of verifications that never ends and some state governments has gone as far as renegotiating with retirees to forgo part of their due pensions in order to receive whatever they may have presented to them. Politicians in political offices are also deploying the payment of pensions as performance indicators hence expect to be applauded by the retirees whose welfare they believe is tied to their apron.

Pension according to ahmed, abayomi and nureni (2016), is the amount set aside either by employer or employee or both to ensure that at retirement, there is something for employees to fall back on as income. it is referred to as a sum set aside for retirement purposes. It is a form of arrangement that hopes that at retirement, retirees will not be stranded financially. furthermore, pension reform is not a new issue in any part of the world. It is usually a continuous process especially with the ever changing economic and political processes witnessed everywhere in the world (blake, 2003). Pension is an amount paid by government or company to an employee after working for some specific period of time, considered too old or ill to work or have reached the statutory age of retirement (adams, 2005). Iwu (2007) mentioned that as a scheme, pension is the periodic payment granted to an employee for services rendered, based on contractual legal enforceable agreement, paid by an employer at the agree time of termination of employment Emphasizing the essence of a pension scheme in an organization, Sterns (2006) states that pensions could discourage labor turnover. If both the employees and employers contribute to the scheme, then it serves as a general area of joint interest and cooperation and therefore helps to foster better employment relations. He stated further that pension administration consists of five basic elements namely: flexibility; that is, to be able to cater for the needs of retirees; amount of benefits which is sum accrued to an ex -employee of an organization; finance, activity of managing pension money; contribution to cost of pension by employee and employer and death benefit that serves as a benefit for beneficiary of a deceased employee. 
In Nigeria, the 2004 pension scheme reforms introduced by the federal government was targeted at changing the narrative by establishing a pension management process that can guarantee retirees their benefit, promote easy access and through the investment of the pension funds bring about returns on investment to the retirees. This reform outside redirecting the pension scheme from defined benefits pension scheme (DBPS) to contributory pension scheme (CPS); also expanded the net of employees covered in pension scheme as many private establishments have keyed into the idea. While many private establishments see this as a way of motivating their workers, others see it as social concern on the welfare of their employees.

Question of employees' commitment among academic staff of private tertiary institutions in Nigeria has become recurring in many academic discuss. This may be attributed basically to the differential in welfare package when compared to what is obtainable in government owned tertiary institutions. According to Schweizer and Patzelt (2012) employee commitment is the employees' decision to stay with a firm regardless of the organizational climate or the change there in. According to Brown, et al (2011) high employee commitment towards organization increases the job satisfaction among employees, job performance, overall productivity, sales and also high employee commitment decreases employee turnover, intention to leave and absenteeism. According to Klein et al., (2012) commitment conveys the significance of a relationship between partners and their will to proceed with the relationship in the future. However when employees sense uncertainty, their will to continue working for the firm dissolves. The view of Klein et al captures succinctly the situation of academic staff in private tertiary institutions especially as it affects uncertainty in job security, welfare package and post retirement life. Some of the private tertiary institutions has introduced pension scheme but how well this scheme has impacted on the commitment of academic staff is yet to be ascertained; this is what this paper is challenged to resolve

\section{Statement of Problem}

The introduction of contributory pension scheme in Nigeria is traceable to the 2004 pension reform Act which was targeted at resolving the numerous challenges associated with the defined benefit pension scheme in practice then. However, the contributory pension scheme cannot be said to be without challenges; issues of accuracy and timeliness in the remittance of benefits to the Retirement Savings Account (RSA) by employers has come to center stage. The pension fund administrators' capacity to rightfully invest the pension funds in investments with high yield is also a challenge. The fear of what becomes the fate of the employees if a PFA or PFC defaults, or went into liquidation has also placed some psychological burden on the perception of the relevance of the scheme on employees or contributors. The end point is that employees' commitment to their organization may be influenced either positively or negatively in line with their thoughts concerning the contributory pension scheme and investigating their thoughts through a verifiable scientific process is the core thrustof this paper.

\section{Objectives of the Study}

The general objective of this study is to examine how contributory pension scheme impacts on the commitment of academic staff in private tertiary institutions in South-East, Nigeria. The specific objectives include; 
INTERNATIONAL JOURNAL OF ACADEMIC RESEARCH IN PROGRESSIVE EDUCATION AND DEVELOPMENT

Vol. 8, No. 2, 2019, E-ISSN: 2226-6348 @ 2019 HRMARS

i. Examine the impact of contributory pension scheme on the affective commitment of academic staff in private tertiary institutions in South-East, Nigeria

ii. Examine the impact of contributory pension scheme on the continuance commitment of academic staff in private tertiary institutions in South-East, Nigeria

\section{Research Questions}

i. Does contributory pension scheme impact significantly on the affective commitment of academic staff in private tertiary institutions in South-East, Nigeria?

ii. To what does contributory pension scheme impact on the continuance commitment of academic staff in private tertiary institutions in South-East, Nigeria?

\section{Research Hypotheses}

$\mathbf{H}_{01}$ : Contributory pension scheme does not impact significantly on the affective commitment of academic staff in private tertiary institutions in South-East, Nigeria

$\mathbf{H}_{\mathbf{0 2}}$ : Contributory pension scheme does not impact significantly on the continuance commitment of academic staff in private tertiary institutions in South-East, Nigeria

\section{Review of Related Literature \\ Contributory Pension Scheme}

Discussions on contributory pension scheme may not be very clear if the concept of pension is not clearly explained. To Gbitse (2008), Pension represents a payment to a worker during the retirement phase of his life to ensure his sustenance and that of his beneficiaries after the active phase of working life. Abdullahi (2007) defined pension as the right of an employee to derive some sort of benefits upon retirement if certain conditions, such as minimum years of service or minimum age have been met. This benefit may be a lump sum called gratuity or periodic payment called pensions. According to Adams (2005) pension is the amount paid by government or company to an employee after working for some specific period of time, considered too old or ill to work or have reached the statutory age of retirement. It is equally seen as the monthly sum paid to a retired officer until death because the officer has worked with the organization paying the sum. In the view of Ozor (2006) Pension consists of lump sum payment paid to an employee upon his disengagement from active service. According to him, payment is usually in monthly installments. He further stated that pension plans may be contributory or noncontributory; fixed or variable benefits; group or individual; insured or trustee; private or public, and single or multi-employer in nigeria, pension administration has evolved through different phases. the most recent in practice is the contributory pension scheme (cps) which is a product of the 2004 pension reform act. elumelu (2005) posits the 2004 pension reform act established a uniform contributory; private sector managed and fully funded pension system for both the public and private sector of the country. The pension reform act 2004 was also established to address the manifested loopholes in the old defined benefit pension scheme and provide adequate resources to retirees after retirement from the service. The large capital pool demands that there should be sound and uniform investment decision making to ensure that value is added to retirement saving account (rsa) contribution. 
Ahmed, Abayomi and Nureni (2016) defined contributory pension scheme as a fully funded pension scheme that generates adequate funds through certain percentage of contributions from monthly earnings by both employee and employer through a form of savings. a major advantage of cps according to Orszag and Orszag, (2000), is that with the mandated investments in private assets, it has the potentials to contribute to the development of capital markets. a cps is also recommended for its potential in raising national savings which increases investment and national income. ibe (2005) posits that the contributory pension scheme is funded in the sense that the contributions and the returns from the investment of such funds provide the resources for meeting the pension obligations. On the contrary, the defined pension benefits scheme is unfunded because the pension obligations are met from the general current revenue, taxation in the case of the government and this is the reason why it is referred to as a "pay-as-you-go" system. Payment of pension obligations in the unfunded pension scheme thus depends largely on general productivity and tax revenue growth in the economy as well as a host of demographic features of the economy. He observes that in the funded pension system, payment of pension obligations would encounter problems if there were earnings problems with pension investments due to management problems and adverse movements in macroeconomic variables. Pensioners under both schemes face risks as to what the future value of their benefits would be, with pensioners under a publicly managed system facing largely political risks and the privately managed contributory pension scheme facing investment risks. While the risks are spread through a market mechanism in the contributory pension scheme, in the defined pension benefits scheme it is through the legislative mechanism, which modifies the benefit plan in the future.

reasons/importance of pension scheme

according to gbitse (2008), pension scheme exist to achieve several objective, the most paramount of which are;

I. Social security: in this regard, pension scheme exist to ensure that people receive some income in their old age to take care of themselves and any dependents. under this objective, proponents of pension schemes realize that individuals are on their own predisposed to improvidence and are unable to make arrangements by them for their old age, except their employers or the governments provide same or establish the necessary structures. for example, the nigerian pension reform act 2004 has assurance of retirement benefits and assisting improvident individuals save for their retirement as part of its cardinal objectives.

ii. Encourage work, ethical behavior and worker productivity: the existence of pension schemes ensure that people are encouraged to work because their lifestyle in retirement is taken care of. also, in developing economies struggling with massive corruption and for certain categories of employees, a defined benefit system may give reasonable assurance and encourage ethical behavior. workers productivity may also be enhanced by defined contribution schemes that encourage worker productivity as contributions are enhanced by promotions, wage increases and additional income which may be tied to productivity e.g. incentive bonuses.

iii. Encourage savings: individual and collective savings are key to individual and family wealth creation as well as national development. Contributory pension schemes ensue that a savings culture is instilled and leads to capital accumulation that is required for societal development. The 
incentive provided by contributory schemes like tax incentives for both employers and employees. fashagba (2012) provided five justifications for pension plans which include: tax advantage of pension, helping people to save for retirement, helping employers to attract the most desired employees, used as severance pay and helping to restructure the workforce and helping to increase productivity

\section{Employees' Commitment}

Lee (2005) referred to organizational commitment as reflecting a person's view to loyalty toward the organization and in-progress processes by the members of an organization, concerning about organizational achievements. Organizational commitment is determined by a number of factors like, personal factors (age, gender, internal and external control properties, and service period in the organization), organizational factors (designing the job and leadership style of a supervisor) and non-organizational factors (existence of a replacement), affecting on organizational commitment. Commitment according to (Jaw and Liu, 2004) is not only a human relation concept but involves generating human energy and activating the human mind. Without commitment, the implementation of new ideas and initiatives will be compromised. (John and Elyse, 2010) Commitment has also been defined as a psychological state that binds the individual to the organization. This binding force can be experienced in different ways that can be accompanied by different mindsets including: an affective attachment and involvement with the target, a felt obligation to the target, and an awareness of the costs associated with discontinuing involvement with the target (Boxall and Macky, 2009).

Affective commitment: refers to the employee's emotional attachment to, identification with, and involvement in the organization. in traditional, ongoing employment relationships, a high level of affective commitment has been found to be related to low employee turnover, low absenteeism and improved job performance hence employees with a strong affective commitment continue employment with the organization because they want to do so (wang, 2010).

continuance commitment: describes an individual's need to remain with the organization resulting from her/his recognition of the costs such as tenure, pay, benefits, vesting of pensions and family commitment associated with leaving the organization. it may also refer to an awareness of the costs associated with leaving the organization. Employees whose primary link to the organization is based on continuance commitment remain because they need to do so (loi and foley, 2008).

normative commitment: reflects an individual's feeling of obligation to maintain organizational membership because he/she believes it is morally right to be loyal to, and stay in, the organization. although normative commitment is widely recognized as a salient dimension of employee commitment, it has been found to be substantially inter-related with affective commitment (coyleshapiro, 2008). Different authors suggest that individuals may display each of these three forms of commitment to varying degrees.

Committed employees are one of the greatest assets any company can have and play a major role in overall business efficiency and profitability. (Hurter, 2008) argues that greater levels of employee commitment lead to organizational benefits such as a continuous flow of improvements, cost and efficiency improvements and active employee participation. Committed employees are believed to enhance an organization as they feel secure in their jobs, are well trained, feel part of a team and are proud thus enjoying doing their jobs (Ho, 2009). Employee commitment also has important 
implications for recruitment. by examining the key drivers of employee commitment, organizations can come up with a list of attributes to guide them when they are recruiting and developing a committed work force other than each year organizations investing substantial amounts of money in training and developing their work force only to see talented and productive employees applying for other jobs, potentially to join the competition (scott, 2007)

The benefits of employee commitment according to Brown, McHardy, McNabb, and Taylor, (2011) are; increased job satisfaction, increased job performance, increased total return to shareholders, increased sales, decreased employee turnover, decreased intention to leave, decreased intention to search for alternative, decreased absenteeism. With this in mind, employee commitment should be viewed as a business necessity.

\section{Method of Data Analysis}

In carrying out this study, the researchers used descriptive survey design and the study covered the five eastern states (Abia, Anambra, Ebonyi, Enugu and Imo State) by focusing on selected tertiary institutions where contributory Pension scheme are practiced. The study involved a population of 611 academic staff from where Taro Yamene was used to select a sample of 242 academic staff. Data collected were analyzed using inferential statistics. The study gathered data mainly through a primary source using a five point likert scale as its major instrument. The Kruskawalis test $(\mathrm{H})$ was employed to test the significance of the research hypotheses, the choice of $\mathrm{H}$ test can be said to be justified since the second variable under study borders on attitude. The data were analyzed using Statistical Package for Social Science (SPSS) 23.0. In oder to determine the proportional contribution of each of the case study states to the sample size, the Bowley's proportional allocation formula was used. It is mathematically represented as; $n_{i}=n N_{i} / N$ Where $n$ represents sample size, $\boldsymbol{N}_{\boldsymbol{i}}$ represents population size of the ith strata and $\boldsymbol{N}$ represents the population of study

\section{Results}

$\mathbf{H}_{01}$ : Contributory pension scheme does not impact significantly on the affective commitment of academic staff in private tertiary institutions in South-East, Nigeria

\begin{tabular}{|c|c|c|c|c|}
\hline SA & A & UND & D & SD \\
\hline 40 & 61 & 33 & 74 & 34 \\
\hline 51 & 70 & 30 & 66 & 25 \\
\hline 43 & 69 & 42 & 61 & 27 \\
\hline 48 & 69 & 46 & 57 & 22 \\
\hline 55 & 64 & 50 & 46 & 27 \\
\hline
\end{tabular}

Source; Field Survey, 2019

NPAR TESTS

/K-W=CPSandAC BY RANKS(1 5)

/STATISTICS DESCRIPTIVES

/MISSING ANALYSIS. 
INTERNATIONAL JOURNAL OF ACADEMIC RESEARCH IN PROGRESSIVE EDUCATION AND DEVELOPMENT

Vol. 8, No. 2, 2019, E-ISSN: 2226-6348 @ 2019 HRMARS

Descriptive Statistics

\begin{tabular}{|c|c|c|c|c|c|}
\hline & & & Std. & Minimu & Maximu \\
& $\mathrm{N}$ & Mean & Deviation & $\mathrm{m}$ & $\mathrm{m}$ \\
\hline CPSandAC & 25 & 48.4000 & 15.89549 & 22.00 & 74.00 \\
RANKS & 25 & 3.0000 & 1.44338 & 1.00 & 5.00 \\
\hline
\end{tabular}

Test Statistics ${ }^{a, b}$

\begin{tabular}{|c|c|}
\hline & CPSandAC \\
\hline Chi-Square & 19.538 \\
df & 4 \\
Asymp. Sig. & .001 \\
\hline
\end{tabular}

a. Kruskal Wallis Test

b. Grouping Variable: RANKS

From the SPSS output for hypothesis, the $\mathrm{H}$ value (Asymp. Sig) is .001 which is less than 0.05 level of significance; it is therefore safe to posit that contributory pension scheme has significant and positive effect on the affective commitment of academic staff members in private tertiary institutions in South-Eastern Nigeria

$\mathbf{H}_{02}$ : Contributory pension scheme does not impact significantly on the continuance commitment of academic staff in private tertiary institutions in South-East, Nigeria

\begin{tabular}{|c|c|c|c|c|}
\hline SA & A & UND & D & SD \\
\hline 19 & 58 & 49 & 72 & 44 \\
\hline 28 & 58 & 54 & 69 & 33 \\
\hline 25 & 49 & 62 & 59 & 47 \\
\hline 37 & 66 & 55 & 63 & 21 \\
\hline 35 & 62 & 44 & 71 & 30 \\
\hline
\end{tabular}

Source; Field Survey, 2019

NPAR TESTS

/K-W=CPSandCC BY RANKS(1 5)

/STATISTICS DESCRIPTIVES

/MISSING ANALYSIS.

Descriptive Statistics

\begin{tabular}{|l|r|r|r|r|r|}
\hline & & & \multicolumn{1}{|c|}{ Std. } & Minimu & Maximu \\
& $\mathrm{N}$ & \multicolumn{1}{|c|}{ Mean } & Deviation & \multicolumn{1}{c|}{$\mathrm{m}$} & \multicolumn{1}{c|}{$\mathrm{m}$} \\
\hline CPSandCC & 25 & 48.4000 & 16.15292 & 19.00 & 72.00 \\
RANKS & 25 & 3.0000 & 1.44338 & 1.00 & 5.00 \\
\hline
\end{tabular}




\begin{tabular}{|c|c|}
\hline & CPSandCC \\
\hline $\begin{array}{l}\text { Chi-Square } \\
\text { df } \\
\text { Asymp. Sig. }\end{array}$ & $\begin{array}{c}.046 \\
4 \\
1.000\end{array}$ \\
\hline
\end{tabular}

a. Kruskal Wallis Test

b. Grouping Variable: RANKS

The SPSS output for hypothesis two shows a $\mathrm{H}$ value (Asymp. Sig) 1.000 which is higher than 0.05 level of significance; it can therefore be said that contributory pension scheme does not have significant effect on the continuance commitment of academic staff members in private tertiary institutions in South-Eastern Nigeria

\section{Discussion of Findings}

The findings from hypothesis one shows that contributory pension scheme can boost the morale of academic staff in private tertiary institutions through the creation of sense of recognition and identification. This however is not enough to get them pledge longevity in service with the private tertiary institutions. The findings from hypothesis two explains why academic staff in private tertiary institutions are quick to accept offers from public tertiary institutions even with the presence of contributory pension scheme in their earlier institutions

\section{Conclusion}

Contributory pension scheme has gained wide acceptance in both the public and private work climate in Nigeria. This study however concludes that there are other intricate work conditions that is needful towards ensuring substantial and sustainable commitment of the employees hence, a right mix of these work conditions should be instituted by the private tertiary institutions on SouthEast, Nigeria

\section{Recommendations}

In line with the findings and conclusion in this study, the researchers recommends as follows;

i. Private tertiary institutions in South-East Nigeria should not only continue with the contributory pension scheme but should ensure its early remittance. Institutions yet to undertake such scheme should endeavor to do so

ii. Paying competitive salaries especially using salary scale of federal government owned tertiary institutions can complement the contributory pension scheme and enhance employees commitment

iii. Beyond contributory pension scheme and other financial tools, ensuring that the social needs of unionism of the academic staff are met can help private tertiary institutions in South-East secure the commitment of their academic staff 


\section{Implications of the Study}

This study took an empirical approach in addressing the issue under discuss. The import of the findings of this study is that administrators of tertiary institutions in the South-Eastern part of Nigeria are expected to rethink their approach towards eliciting the commitment of their academic staff by paying competitive salaries, engendering social affiliations through unions and above all ensure the full and timely implementation of the contributory pension scheme. This is expected to reduce turnover intentions among the academic staff while enhancing their affective and continuance commitment to the institutions

\section{References}

Abdullahi, Y. (2007). Pension administration in nigeria: an overview. The nigerian journal of administrative studies. Vol. 5 no. 2

Blake, D. (2003). United Kingdom Pension Scheme in Nigeria Pension Institute, Bareback College University of London.

Boxall, and Macky. (2009). Research and Theory on High Performance Work Systems:Progressing the High-Involvement Stream. Human Resource Journal, Vol 6,pp. 3-23

Brown, S., McHardy, J., McNabb, R., \& Taylor, K. (2011). Workplace Performance, Worker Commitment and Loyalty. Bonn: Institute for Study of Labour (IZA)

Coyle-Shapiro, M. A. (2008). Serving two organizations: Exploring the employment relationship of contracted employee. Human Resource Management, Vol.45,pp.561-583.

Elumelu, T. (2005). Investment, finance and banking in Nigeria: Evolution and new opportunities. Lecture delivered at the 2005 US - Africa summit of the Corporate Council on Africa, Baltimore, USA.

Gbitse, B. (2008). Pension Fund Administration in Nigeria. Abuja, Pen \& pages Printers Ltd.

Hurter, N. A. (2008). The Role of Self-Efficacy in Employee Commitment. Johannesburg: University of South Africa

Ho, G. L. C. (2009). Empowerment in a Technology Advanced Environment. Industrial Management and Data Systems, 24-42.

Ibe, A. C. (2005). The Opportunities and Challenges of the New Pension Scheme for Financial Institutions in Nigeria, Union Digest, Vol. 9, Nos. 3\&4, December, 2005, pp 83-95.

Iwu, M. (2007). Study of the Impact and Implication of Restructuring the Nigeria Pension Scheme, A Study of Enugu State, Nigeria. An unpublished thesis submitted to University of Nigeria, Enugu Campus.

Jaw, B., and Liu, W. (2004). Promoting Organizational Learning and Self Renewal in Taiwanese Companies: The Role of HRM. Human Resource Management, 42 (3), 223 -241

John, P., \& Elyse, R. A. (2010). Employee commitment and well-being: A critical review, theoretical. Journal of Vocational Behaviour

Lee, Jean. (2005). Effects of leadership and leader-member exchange on commitment. Leadership \& Organization Development Journal. 26. 655-672. 10.1108/01437730510633728.

Loi, R, \& Foley, H. Y. A. (2008). Linking employees justice perceptions to organizational commitment and intention to leave: the mediating role of perceived organizational support. Journal of Occupational and Organizational Psychology, Vol.79,pp.101-120 
Oladipo, J. A. \& Fashagba, M. O. (2012). Evaluation of Compliance with the Stipulations of the Contributory Pension Scheme: A Case Study of Quasi-Government Institutions in Nigeria An International Multidisciplinary Journal, Ethiopia (Pp.59-75) Vol. 6 (4),

Orszag, J. M. \& Orszag, P. R. (2000). The benefits of flexible funding. Implications for pension reforms in an uncertain world, abcde, pp. 373391.

Ozor, E. (2006). Review of Factors that Slow Down the Processing of Retirement Benefits, A Paper Presented at the Workshop Organized by the Institute of Chartered Secretaries and Administration of Nigeria, Held at Modotel Enugu

Schweizer, L., \& Patzelt, H. (2012). Employee commitment in the post-acquisition integration process: The effect of integration speed and leadership. Scandinavian Journal of Management, 28, 298-310

Scott, B. (2007). What Impact Does Training Have on Employee Commitment and Employee Turnover. Kingston: University of Rhode Island.

Sterns, W. L. (2006). Work and Retirement in Older Society in Our Aging Society, Paradox and Promise, A. Pifer and L. Bronte eds, New York: Carnage Corporation. pp. 341-365

Wang, I. A. (2010). Affective and continuance commitment in public private partnership. Employee relations, journal of human resource management. Vol 32.4,396-417. 